\title{
Estigma moral e sofrimento psi: problematizando a individualização do superendividamento do consumidor
}

\section{Moral stigma and psychological suffering: problematizing the individualization of consumer overindebtness}

\author{
I nês Hennigen* \\ Universidade Federal do Rio Grande do Sul - UFGRS, Porto Alegre, Rio Grande do \\ Sul, Brasil
}

\section{J oão Paulo Borges**}

Universidade Federal do Rio Grande do Sul - UFGRS, Porto Alegre, Rio Grande do Sul, Brasil

\begin{abstract}
RESUMO
Em face da ausência de estudos no campo da Psicologia Social sobre o tema, desenvolvemos uma pesquisa exploratória que objetivou conhecer as implicações subjetivas da situação de superendividamento do consumidor. Entrevistamos 24 consumidores que, estando nessa condição, aderiram a um projeto do judiciário gaúcho que propõe a conciliação paraprocessual com os credores; realizamos a análise do material obtido nas entrevistas em consonância com a metodologia da análise de discurso. Dois aspectos interligados que se evidenciaram - a individualização e a dimensão moralizante do superendividamento, que acarretam considerável sofrimento psíquico aos sujeitos - são discutidos e problematizados aqui a luz da perspectiva foucaultiana e das proposições de Nietzsche sobre a moral. Indicamos a necessidade de políticas públicas e estratégias de enfrentamento que considerem a complexidade da situação.
\end{abstract}

Palavras-chaves: superendividamento, subjetivação, moral, consumo, crédito.

\begin{abstract}
Given the lack of studies in the field of Social Psychology on this topic, we developed an exploratory research aiming to know the subjective implications of consumer's overindebtedness. We interviewed 24 consumers who, being in this condition, joined a project developed by the southern Brazil Judiciary, which proposes legal paraprocedural conciliation with creditors. We analyzed the material obtained in interviews according to the methodology of discourse analysis. Two interrelated aspects that were revealed - individualization and the moralizing dimension of overindebtedness, which cause considerable psychological distress to the subjects - are discussed and problematized here in the light of Foucault's perspective, and Nietzsche's propositions about morality. We indicate the need for public policies and facing-up strategies that take into account the complexity of this situation.
\end{abstract}


Keywords: overindebtedness, subjectivation, moral, consumer, credit.

\section{Notas sobre a produção sócio-histórica do superendividamento}

A passagem do feudalismo ao capitalismo foi marcante em termos de organização econômica e geopolítica, e igualmente pela transformação das relações sociais: as relações do ser humano (consigo, com os outros e com as instituições) passam a ser mediadas pelo capital, sendo deslocadas de sua finalidade "original". O trabalho, por exemplo, passa a ser realizado não para se obter um produto final, mas para se auferir rendimentos que permitam 0 acesso a qualquer tipo de bem, inclusive os para a subsistência. Ao mesmo tempo, quem detém os meios de produção não produz mais só para suprir carências, mas visa o acúmulo de capital (Barros, 2007).

Na chamada sociedade de produtores, marcada pela industrializaçãourbanização, a finalidade é a produção. Mas que sentido ela tem quando as cidades, abarrotadas de fábricas e de trabalhadores, não dão vazão a seus produtos? Quanto maior a produção, mais necessário é que se consuma. É neste desenvolvimento social em torno da máquina econômica que pudemos assistir à transição da sociedade de produtores a uma sociedade de consumidores. O imperativo ao consumo pretende botar mais carvão na caldeira da locomotiva capitalista. Para que os produtos se vendam tem de haver demanda; então, essa não pode ficar no nível parcimonioso da necessidade vital. Como bem pontua Baudrillard (1995), a necessidade sai do nível da vida orgânica e se desdobra ao nível da vida social, através do valor simbólico adquirido pelos produtos na cultura.

Os objetos deixam de estar ligados a uma função ou necessidade definida, deslocando o significado do ato de consumir. Em um jogo de signos-significantes, de poder que a posse de determinados bens confere, "a circulação, a compra, a venda, a apropriação de bens e de objetos/signos diferenciados constituem hoje a nossa linguagem e 0 nosso código, por cujo intermédio toda a sociedade comunica e fala" (Baudrillard, 1995, p. 77). É através desse processo que a ideia de "ter para ser" ganha força e convoca, implicitamente, os sujeitos à compra e à ostentação. Maffesoli (2000, como citado em Bauman, 2008 , p. 107) sintetiza: "sou o que sou porque outros me reconhecem como tal", enquanto "a vida social empírica não é senão uma expressão de sentimentos de pertenças sucessivas"; ele evidencia, assim, as bases da constituição psíquica do ser humano forjadas nesse contexto. 
Baudrillard (1995) sugere a expressão Menor Cultura Comum para falar daquilo que o sujeito deve saber para conviver em determinada sociedade; algo como uma ética compartilhada que será respaldada com peso de lei por aqueles que comungam num grupo. Daí provém uma moralidade, o correto ou incorreto a se fazer, a ser, afinal. Assim, se, na sociedade de produtores, o senso de pertença vem através do "dever produzir", na de consumidores ele se dá pelo "dever consumir". Nesse sentido, a necessidade de consumir é construída socialmente sobre a necessidade de interagir e pertencer (Bauman, 2008).

Por tudo isso, concebemos que o ser humano se torna sujeito, de certos modos, face aos discursos e práticas que se constituem nos diferentes contextos histórico-sociais - inexistindo, portanto, um modo de ser sujeito a priori, atemporal, uma essência psicológica. Importante ressaltar que, nesse processo, sempre incidem mecanismos que exaltam modos de ser voltados à sustentação da configuração social dada e, correlativamente, que criam formas de alteridade fadadas à segregação (Foucault, 1995).

Historicamente, se o crescimento da produção teve de gerar aumento do consumo, o imperativo ao consumo encontrou, na segunda metade do século $X X$, a antecipação de recursos, na forma de financiamentos, como a maneira mais eficaz de se potencializar.

Sociedade do Endividamento é um termo que Guttmann e Plihon (2008) empregam na análise dos processos econômicos que foram engendrando os fenômenos que (vi)vemos hoje. Sua constituição remonta ao enfrentamento da crise do final dos anos 1920, quando a economia parou no crack da bolsa de Nova Iorque. Nesse contexto, inspirado nas críticas de Keynes ao liberalismo, o governo norteamericano que assumiu em 1933 propôs um programa de reformas e recuperação do país - o New Deal - que teve três focos: lutar contra o desemprego, sanear a agricultura e revigorar a economia. Nesse último âmbito foram implementadas reformas monetárias que alavancaram e conferiram credibilidade ao sistema bancário.

Assim, além de contribuir para a recuperação econômica americana, tal sistema bancário seguro foi o pilar do boom do pós-guerra, pois pode financiar o rápido crescimento econômico. E aquilo que começou em uma relação entre bancos e Estados-governo, logo passou às empresas do setor privado e, então, às famílias (Guttmann \& Plihon, 2008); para as últimas, a possibilidade da antecipação de recursos representou a elevação do poder de compra - e, em alguns casos, mesmo a garantia de meios de sobrevivência. Desse modo, acabou inaugurando-se uma nova maneira de se viver, descolando as práticas de consumo dos limites de renda.

Se o crédito representa uma não circunscrição do acesso a bens e serviços àquilo que de fato se tem como receita, carrega também consigo, além da possibilidade de desenvolvimento, um risco 
potencial: sendo os indivíduos aqueles que de fato sustentam as instituições financeiras, e essas, em certa medida, o Estado, níveis altos de inadimplência podem significar a falência não só dos bancos, mas de toda uma nação.

Neste sentido, a condução das condutas - dos indivíduos com suas especificidades, mas enquanto concebidos como população - quanto ao uso do crédito e ao endividamento configura-se como uma questão biopolítica, pois diz respeito à vida em variadas dimensões. Foucault (2008) mostra que foi justamente a emergência do problema da população que marcou uma virada na arte de governar; assim, aponta esse autor, desde o século XVIII o Estado passou, cada vez mais, a ser governamentalizado.

Por esta palavra, "governamentalidade", entendo o conjunto constituído pelas instituições, os procedimentos, análises e reflexões, os cálculos e as táticas que permitem exercer essa forma bem específica, embora muito complexa, de poder que tem por alvo principal a população, por principal forma de saber a economia política e por instrumento técnico essencial os dispositivos de segurança. (Foucault, 2008, p. 143)

Uma vez que a governamentalidade é, ao mesmo tempo, interior e exterior ao Estado, não surpreende, portanto, o surgimento e atuação de agências de monitoramento de crédito (como o Serviço de Proteção ao Crédito e a Serasa Experian, entre outras). Tais instituições permitem um mapeamento e controle da situação econômica de determinadas regiões e populações, uma análise do comportamento comercial em dado cenário. Isso serve ao próprio sistema comercial e bancário, e também ao Estado, que pode, então, por meio de regulamentações (leis) e regulações (incentivos fiscais, por exemplo), manejar as relações comerciais e de consumo, de forma a, fomentando o consumo via crédito, buscar manter afastado o perigo do inadimplemento generalizado.

Podemos citar como práticas desse monitoramento as pesquisas e levantamentos regulares realizados por tais agências, que permitem uma visualização, em nível macro, dos fenômenos sazonais concernentes à intensidade do consumo, à tomada de crédito e à situação econômica das famílias. Por exemplo, conforme a "Pesquisa Nacional de Endividamento e Inadimplência do Consumidor", realizada pela Confederação Nacional do Comércio de Bens, Serviços e Turismo $(2011)^{1}: 58,6 \%$ das famílias consideravam estar endividadas, $21,2 \%$ tinham contas em atraso e $7,2 \%$ declararam não ter condições de pagá-las; o cartão de crédito respondia por 73,1\% das dívidas; e 15,4\% dos participantes consideravam-se "muito endividados". Recentemente, outro levantamento, realizado pelo Serviço Central de Proteção ao Crédito (D'Andrade, 2012) ${ }^{2}$ mostrou 
que "o registro de consumidores inadimplentes no País aumentou $22,3 \%$ em 2011, na comparação com o ano anterior" e que "o mês de dezembro de 2011, em relação ao último mês de 2010, apresentou alta de $15 \% "$.

Se as agências de monitoramento contribuem para um diagnóstico e para as regulações (que incluem também a restrição de crédito), o campo do Direito - que congrega conhecimento, pesquisa e debate além de fazer cumprir as regulamentações, acaba sendo um espaço para análise do contexto sócio-histórico da sociedade, de maneira que as leis possam ser revistas, ampliadas, revogadas. As situações de superendividamento do consumidor são exemplares desta potência do campo jurídico brasileiro nos dias atuais. Com o fomento à tomada de crédito, esse passa a ser o próprio produto a ser consumido, o que tem gerado inúmeras demandas ao judiciário, realçando o vacúolo legal que se apresenta. Por isso, faz-se necessário rever a legislação no que tange ao Direito do Consumidor, já que esse, além de consumidor em geral, é também consumidor de crédito.

Foram países europeus os primeiros a entender a necessidade e a desenvolver uma legislação específica sobre o que vem sendo designado com o fenômeno do superendividamento do consumidor. Por se tratar de uma questão relativamente recente em nosso país, é escassa a literatura a respeito do tema. É mérito de pesquisadoras como Marques e Cavallazzi (2006) e Lima e Bertoncello (2010) terem desenvolvido já o primeiro olhar sobre o fenômeno, legando um saber pioneiro e muito pertinente sobre o cenário atual e os desafios que ele nos impõe. A primeira, inclusive, elaborou a definição mais referida de superendividamento: "impossibilidade global de o devedor pessoa física, consumidor, leigo e de boa-fé, pagar todas as suas dívidas atuais e futuras de consumo", o reconhecendo como um "fenômeno social e jurídico" (Marques, 2006, p. 256). As duas últimas autoras tem desenvolvido, no judiciário gaúcho, o "Projetopiloto Tratamento das Situações de Superendividamento do Consumidor", onde se busca um acordo paraprocessual entre consumidores superendividados e a totalidade de seus credores, por meio de audiências de conciliação. A iniciativa, que visa a sensibilização dos credores, pretende propiciar ao consumidor a assunção de um compromisso adequado ao seu orçamento familiar.

A própria experiência no âmbito do referido Projeto, assim como os achados de algumas pesquisas internacionais (Frade \& Magalhães, 2006) tem sugerido uma convocação à Psicologia para além das explicações que circundam e restringem-se às noções de "compulsão" ou "desmedida", já que apontam trata-se de um fenômeno de ordem social e que tem repercussões subjetivas importantes.

Assim, na busca de uma abordagem das questões concernentes ao superendividamento na perspectiva da psicologia social, a pesquisa 
que realizamos teve como objetivos: por um lado, conhecer suas implicações subjetivas - o que abarcou explorar, entre outros aspectos, como é sentido e concebido, as condições de vida que levam a sua ocorrência, as repercussões nas relações sociais, as formas de enfrentamento e as eventuais alterações no período pósacordo com credores; por outro lado, entender o papel da mídia e da publicidade na sua produção - o que nos levou a focalizar o contato que os consumidores tiveram com a publicidade do crédito e sua percepção da mesma; e se e o que identificavam na mídia como valores relacionados a seus modos de ser e às suas práticas de consumo. Importante ressaltar que, no presente artigo, trazemos resultados e discussões relativos a aspectos atinentes à primeira linha de investigação.

\section{Abordagem metodológica}

Por se tratar de uma pesquisa exploratória, o planejado era entrevistar dez consumidores que aderissem, no PROCON/RS, ao "Projeto-piloto Tratamento das Situações de Superendividamento do Consumidor"; eles seriam entrevistados em dois momentos: logo após a adesão ao Projeto e três meses depois da audiência de conciliação, em caso de acordo. No entanto, alterações foram realizadas em face de circunstâncias não previstas. Quando da etapa de campo, poucos consumidores procuraram tal órgão em função do Projeto, o que fez com que buscássemos outras instituições integrantes do Projeto para contatá-los. Informados de que nem sempre as audiências eram exitosas, elevamos o número de participantes para quinze, a fim de assegurar a realização da segunda entrevista. Contudo, somente uma consumidora, entre os quinze iniciais, conseguiu efetivar acordo (por ausência do(s) credor(es), propostas não aceitas, desistência, etc.). Por isso buscamos, junto ao órgão que organizava as audiências, mais nove pessoas que efetivamente tinham logrado acordo.

Desse modo, participaram da pesquisa 24 consumidores, que serão, na sequência descritas, identificados como C1 para consumidor 1 e assim sucessivamente ${ }^{3}$. Quanto às características pessoais, tivemos 0 seguinte quadro: 13 mulheres e 11 homens; 7 na faixa entre 21 e 39 anos, 10 com idade entre 40 e 59 anos, e 7 na faixa entre 60 e 73 anos; nível de escolaridade desde o ensino fundamental incompleto até o superior completo; estado civil, ocupações e montante das dívidas dos mais variados.

O convite para integrar a pesquisa era feito pelo servidor do órgão que atendia o consumidor; caso ele mostrasse interesse, era encaminhado diretamente, quando lá nos encontrávamos, ou fornecia um telefone para marcarmos um encontro no órgão ou na 
Universidade. Nesse, após conhecer o teor da pesquisa e formalizar sua participação assinando o Termo de Consentimento Livre e Esclarecido, realizava a primeira entrevista. Essa se configurou como semiestruturada, pois comportava questões norteadoras (baseadas nos aspectos objetivados pelo estudo), mas tinha caráter aberto e não obedecia a um sequenciamento, permitindo ao consumidor discorrer sobre os aspectos por nós levantados e agregar outros elementos. A segunda entrevista, planejada para enfocar a experiência da audiência e as eventuais mudanças pós-acordo, acabou sendo alterada: para os nove novos participantes, incorporamos aspectos básicos abordados na primeira.

Todas as entrevistas foram realizadas em ambiente reservado e registradas em áudio; depois de sua transcrição, procedemos ao processo de análise; o método utilizado foi o da análise de discurso (Foucault, 2000; Orlandi, 2000). Nesta perspectiva metodológica, trabalha-se a superfície do discurso, buscando o que se enuncia; entende-se que uma enunciação, o que cada sujeito diz, só é possível acontecer (é dizível) se sustentada por redes discursivas (produzidas no tecido social, que transcendem aos sujeitos falantes, que são fruto do embate de forças constitutivo das relações saber-poder) que the outorguem valor e coerência, articuladas num contexto sóciohistórico. Assim, no trabalho de análise, procuramos examinar os ditos que atravessavam os materiais. Para tanto, em um primeiro momento, fomos mapeando o que se evidenciava nas entrevistas, de modo a visibilizar o que estava sendo dito no que concerne ao superendividamento. Em decorrência desse movimento de análise, algumas questões que se enunciavam foram se destacando. Então, elas foram sendo multiplicadas, isto é, buscamos suas condições de existência, as relações que constituem, como vão se engendrando mutuamente, e, algo que é fundamental nesta pesquisa, as posições de sujeito, os modos de subjetivação, que põem em cena.

\section{Superendividamento e mal-estar psi: individualização e moralização}

Um aspecto que se mostrou relevante no que concerne às implicações subjetivas do superendividamento foi o mal-estar que a grande maioria dos participantes referiu sentir por ter dívidas e não conseguir saldá-las. Constatamos que a forma, escopo e grau da aflição e mobilização pessoal apresentavam variações, contudo, em geral, eram bastante significativos no que dizia respeito a impactar sobre a qualidade de vida desses sujeitos. Ponderando sobre tais achados, compreendemos que guardavam estreita relação com duas questões que se associavam: a individualização do fenômeno e sua dimensão moralizante. 
Ao refletir sobre seu (super)endividamento ${ }^{4}$ e expor as vicissitudes da sua vida em função do mesmo, os consumidores trouxeram uma gama de sentimentos que lhes acometia. Assim, o mal-estar psicológico sentido foi expresso como ansiedade, vergonha, stress, sentimento de impotência, de culpa, de humilhação, angústia, pânico, desânimo, dentre outros. Tais sentimentos compunham e mesclavam-se aos sofrimentos de diferentes ordens que relataram experimentar: depressão, insônia, afetação das relações familiares, falta de perspectiva - de solução do problema, de vida.

"Me sinto deprimida, me sinto nervosa, me sinto doente psicologicamente." (C10)

"A gente não dorme, né, quando tá devendo?! É impressionante... e é isso... é uma sensação, assim, de.... quase de impotência frente a isso, assim... sabe... tentar resolver e não conseguir e tal." (C19)

"Nós perdemos toda aquela garra, aquela força que a gente tinha... em termos de dívida... isso aí tá prejudicando, afetando, não só a mim, como à família." (C22)

Alguns consumidores, ao relatar seu mal-estar, evidenciaram mais explicitamente uma faceta daquilo que chamamos aqui de dimensão moralizante do superendividamento. Isso porque colocaram que o incômodo constante que sentiam em função da situação decorria da pressão da sua consciência - que os lembrava das dívidas; que, além de lembrar, dizia não ser correto, justo ou certo deixar de pagar o que se deve.

"Mas é que a minha consciência não é assim, a gente sempre foi uma família muito justa, de pagar o que deve; isso aí tava me perturbando. Muito." (C17)

Como afirmamos acima, o mal-estar estava presente na experiência cotidiana da grande maioria. Entretanto, apesar do pequeno número, julgamos importante trazer as colocações das quatro entrevistadas que apresentaram posições diferentes: uma disse que "não me afeta no meu eu, porque eu me viro com o $X$ [tipo de crédito] do $Y$

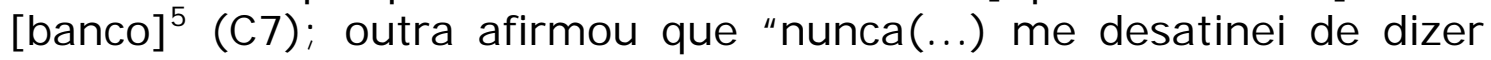
assim 'agora eu não tenho mais saída', né (...) eu já corri muito atrás, sei também que saio dessa(....) eu tapo aquele [empréstimo], abro outro" (C5); a terceira (inadimplente por anos sem se preocupar, apesar de não considerar correto ficar devendo), ao constatar que tal condição atingiria seus planos para a filha [conseguir bolsa em uma escola particular], asseverou que "agora, eu tô mal! Mudou o peso, a responsabilidade" (C20); finalmente, a quarta foi contraditória, pois primeiro contou que, em conversa com uma amiga, "eu disse "porque eu tô apavorada, porque eu tô no SPC'" e, em outro momento da entrevista, colocou que "olha, pra mim não é polêmico [estar no $\mathrm{SPC}$." (C18)

Com base nesses e em outros elementos que surgiram nas entrevistas com essas consumidoras, pareceu-nos que as duas 
primeiras estavam bem sintonizadas com a atual cultura do endividamento: ter dívidas e buscar mais crédito para cobri-las faz parte do modus operandi do consumidor contemporâneo (Bauman, 2010) e isso não é (não deveria ser?) encarado como problemático. Por outro lado, a despeito de ter uma avaliação negativa sobre ficar devendo, a mudança de posição da terceira afigurou-se mais como uma decorrência das restrições concretas que vislumbrou; já a última demonstra oscilar acerca do estatuto do endividamento e da inadimplência.

A despeito dessas posições divergentes, a afirmação proferida na fala a seguir foi uma espécie de voz corrente entre os participantes: "A situação normal é essa, é tar com o nome limpo!" (C23). Nesse posicionamento aparece outra face da dimensão moralizante: há uma norma, deve-se pagar - ou honrar (verbo muito usado nesses casos) - as dívidas assumidas, sendo que tal conduta assegura a credibilidade comercial, o chamado "nome limpo na praça". Contudo, verifica-se que tal norma acaba ultrapassando esse âmbito e passa também a se referir e demarcar a credibilidade social dos sujeitos, sua reputação. Quando alguém está endividado e não paga independente das circunstâncias e de reunir, ou não, meios para fazê-lo - , uma espécie de véu de desconfiança, de descrédito moral, Ihe cobre, seu nome fica sujo (para além do seu CPF - Cadastro de Pessoa Física) figurar nos cadastros de inadimplentes, como SPC e SERASA). Assim, a difusão de tal racionalidade confere consistência ao que chamamos de dimensão moralizante: as dívidas, que, a princípio, concernem à esfera financeira, passam a desabonar a própria pessoa. Neste sentido, parte dos consumidores, ao falar da sua situação, tentou logo de início se distanciar da pecha de desonestos, trazendo a baila e negando expressões e visões pejorativas que socialmente são associados aos devedores.

"Não foi por mau-caratismo, foi porque realmente eu tive problemas e não pude quitar, né." (C2)

"Acho horrível essa situação de caloteira, né(...) eu quero saldar minhas dívidas, só que realmente assim, fugiu do meu controle, né." (C4)

Ao buscar contextualizar sua própria situação e enfatizar que são pessoas de boa-fé, diferente de outras que (talvez) não seriam, alguns entrevistados traçaram uma distinção entre consumidores como eles, que tiveram problemas, e aqueles que, por exemplo, gastam a mais, que não se importam com a inadimplência - o que só reforça o ideário individualizante; dois consumidores foram mais além e estabeleceram uma diferenciação cruzada entre honestidade e condição socioeconômica do devedor.

"Ah, tem uns que gastam, eu acho, a mais, mas... a maioria eu acho que aconteceu que nem eu, assim, de uma hora pra outra... me vi sem saída, né. ( $\mathrm{C} 1$ ) 
“Ah, a gente fica chateado, né.... Tem gente que 'ah, é normal!' Cada um, cada um, né! ....

Digo 'ah, pra ti, tudo bem, mas pra mim é chato!' Eu nunca, nunca tive problema com SPC, nunca entrei." (C6)

"Porque quem não quer pagar dívida, simplesmente não procura um local pra não pagar; deixa rolar. A gente tentou... a gente é pobre e pobre é honesto." (C8)

Para agregar outros aspectos à problematização da racionalidade moralizante que acaba se imiscuindo na questão do superendividamento e sua individualização, consideramos fundamental pontuar que na história dos consumidores entrevistados, quase invariavelmente, ocorreram eventos exteriores à sua vontade. Como no estudo realizado por Marques (2006), para os participantes desta pesquisa o (super)endividamento também esteve associado ou aconteceu em decorrência dos chamados "acidentes de vida": separação (C2, C4, C13, C14, C23, C24); doença na família (C2, C7, C13); perda de familiar (C2, C3, C5); nascimento de filho (C20, $\mathrm{C} 22)$; desemprego pessoal, de cônjuge ou de filho que morava junto (C1, C10, C12, C13, C15, C17, C21, C22, C24); negócio próprio malsucedido (C3, C6, C8, C13, C17, C19); renda estagnada ou que diminuiu (C5, C9, C24); mudança, construção/reforma da casa, despesas extras com condomínio (C4, C9, C10, C16, C18, C22); doença ou acidente pessoal (C11, C21). Somente uma consumidora (C5) atribuiu o seu constante (super)endividamento à impulsividade.

Outro aspecto bastante relevante para problematizar a individualização do fenômeno é que, além dos acidentes de vida, o (super)endividamento dos participantes também aconteceu em função do fator contrato de crédito. Através dessa expressão nos referimos às condições que regem a concessão de crédito (incidência de juros, taxas, multas, tarifas, etc.) nas suas mais variadas formas. Não investigamos se os participantes tiveram efetivamente acesso aos contratos na íntegra para tomar conhecimento formal prévio das suas condições. Porém verificamos que, quase invariavelmente, elas não eram bem compreendidas e/ou dimensionadas pelos mesmos. Por exemplo, alguns relataram que fizeram compras com cartão de crédito ( $e$, na falta de recursos, só efetuaram o pagamento mínimo durante um período), mas que somente a posteriori, depois de constatarem que o montante devido crescia exponencialmente, se deram conta que a taxa de juros era muito elevada, percebendo assim o chamado efeito cascata do pagamento mínimo. Porém, observar isso, em certos casos, não assegurou saber dimensionar quanto realmente deviam - e, principalmente, em função de que tarifas e quais percentuais. Os consumidores até passaram a utilizar termos como "bola de neve" para expressar a incidência de juros ou o círculo vicioso que é tomar um empréstimo para pagar o anterior, 
mostrando certa compreensão. Entretanto, vários deles, frente ao montante da dívida que lhes foi apresentado quando buscaram (re)negociá-la, surpreenderam-se, o que denota que realmente ainda não tinham claro o que significava, em termos monetários, o patamar de juros e/ou a "lógica" do tipo de crédito que contraíram. Por vezes, o mesmo consumidor mostrou aprendizagem sobre um aspecto, mas seguia não compreendendo outro.

“Porque a gente pensa assim: 'vou pagar o mínimo' e na verdade não existe o mínimo, o mínimo deles é o juro que tem embutido." (C5)

"É aquela coisa: tu tira um empréstimo pra pagar o outro e tira outro pra pagar outro, e tu nunca consegue sair daquela bola de neve, né?" (C9)

“Daí comecei(...) não tava dando, daí fui no banco, o banco negociou metade do meu limite(...) fez tipo se fosse um novo empréstimo, daí é 62 e pouco que eu pago." (C4)

"Faltariam duas para terminar o meu compromisso com eles, foi gerada uma nova dívida, no valor de 108 reais, ou 107(...) em oito vezes! Eu tô pagando 800, quase 900 reais a mais daquilo que eu devia!" (C10)

"A minha dívida, que era de 999 quando eu comprei [em 2006], tava em 6 mil [em 2010], eu acho agora, 5, 4, sei lá quanto!" (C18)

Os realces nos três últimos excertos mostram que: a primeira consumidora não tinha clareza que sim, havia contraído um novo empréstimo (saberia então das suas condições?); a segunda (que comprou no cartão em 18 vezes, tendo efetuado pagamento mínimo durante vários meses) parecia guiar-se por um princípio relativo aos carnês (prestações mensais) e, por isso, imaginava inclusive estar sendo lesada; a última considerava excessivo o montante da sua dívida (apesar de não sabê-lo ao certo), pois o comparava com o valor da compra, sem avaliar a incidência de juros (do cartão de crédito, um dos mais altos) ao longo de quatro anos.

Presumimos que, tal como esses consumidores, muitos outros também acabem enredados em dívidas desconhecendo sua magnitude. Estudiosos do campo do Direito (Marques \& Cavallazzi, 2006) ressaltam que, segundo nosso Código de Defesa do Consumidor ( $C D C)$, o fornecedor de produtos e serviços deve disponibilizar informações suficientes para que o consumidor possa decidir sobre o negócio de forma segura. Portanto, a aprendizagem sobre os meandros das diversas modalidades de crédito deveria acontecer previamente à sua concessão, o que não se verifica na prática. O que acompanhamos hoje é o crescimento de um discurso que diz que o consumidor deve ser consciente ao tomar crédito. Contudo, cada vez mais, basta apertar algumas teclas em um terminal bancário eletrônico, ou dizer sim a um operador de telemarketing de empresa de cartão, para ter crédito à disposição. Cabe perguntar: em que instâncias sociais se aprende a "organizar" 
as finanças, a lidar com a enxurrada de "oportunidades" de consumo e de crédito, a compreender o que designamos aqui como "Iógica" do crédito? E indagar: em que medida as práticas da mídia e da publicidade colaboram para produzir o desconhecimento e também o "descontrole" que acaba sendo imputado ao indivíduo-consumidor?

Questões complexas, que discutiremos em outro escrito, mas que, apenas pelos aspectos apontados aqui, já podem ser tomadas como cerne desse fenômeno. Contudo, a despeito de tudo isso, o que verificamos é que o consumidor acaba sendo identificado como o responsável pelo superendividamento. Assim, toda uma rede de fatores (que inclui políticas governamentais de estímulo ao consumo e de ampliação do crédito; o rentabilíssimo negócio do crédito no Brasil, que pratica juros sem igual no mundo; o aumento do custo de vida sem o crescimento dos salários; a falta e/ou insuficiência de políticas públicas e de equipamentos sociais que amparem o cidadão; e a própria cultura do consumo e do endividamento, que tem no marketing/publicidade porta-vozes astutos) acaba invisibilizada quando alguém se encontra em situação de superendividamento. $O$ que acontece é se atribuir ao indivíduo a "culpa" pela situação - por motivos que vão desde a falta de controle/planejamento financeiro, passam pela ideia de impulsividade ou compulsão, chegando até às (supostas) falhas de caráter.

Desse modo, o fenômeno do superendividamento acaba sendo circunscrito a "um", resta individualizado: teria como origem o próprio indivíduo. Nessa operação, as ações e intenções do consumidor passam por um crivo valorativo; como se supõe que são (somente) elas que provocaram uma condição recriminada socialmente, o próprio sujeito parece ter que arcar com o ônus (des) moralizante.

Por tudo isso, não surpreende que muitos entrevistados, apesar de terem ciência das circunstâncias de suas vidas e/ou das condições do crédito como fundamentais para a ocorrência do seu (super)endividamento, referiram sentir culpa, constrangimento, vergonha, e responsabilização pessoal por tudo que a situação implica. $O$ entrevistado abaixo, que teceu críticas bastante consistentes à cultura do consumo, ao falar de sua situação, parece esquecê-las e faz recair sobre sua "cabeça" toda a culpa.

"Bah... ainda me culpo por causa disso, né, porque(...) onde é que eu tava com a cabeça de gastar tanto assim?! Não sei!" (C15)

"Eu acho muito constrangedor, sabe, tu atender o telefone, na frente dos teus colegas, e ser alguém te cobrando, tu tenta dar um desdobre; que eu não sei se é normal, mas eu morro de vergonha! (...) Faz parte do jogo, né?" (C4)

“Foi uma má administração minha, em questões financeiras, de não prever um valor a mais pra essas coisas.... para sanar aquelas taxas que até então, pra mim, não eram claras." (C16) 
A posição externada pelo último consumidor é emblemática no que concerne ao que designamos como individualização do superendividamento: ao comprar um apartamento, ele não sabia de certas taxas (o corretor não lhe informou), mas mesmo assim concebe que o problema decorreu de uma má administração pessoal. Provavelmente por ser sensível aos discursos sobre como as pessoas são ou não são economicamente conscientes e controladas (como se fosse uma "característica inata"). Já a consumidora anterior, ao dizer que a cobrança (quase pública, constrangedora, no caso) faz parte do jogo, parece assumir que esse tipo de procedimento - que frequentemente toma a forma de uma repreensão/punição simbólica reiterada - é algo a que, quem deve, não só está sujeito, mas é uma espécie de prerrogativa do credor, um ônus a ser suportado pelo devedor.

A despeito do superendividamento, em geral, levar à inadimplência, alguns consumidores, ao constatar a impossibilidade de pagar as dívidas, buscam estratégias postergadoras, como fazer só o pagamento mínimo do cartão ou contrair novos empréstimos medidas para evitar o (fatídico) registro nos cadastros de inadimplentes. Traduzido popularmente pela expressão "estar com o nome sujo", tal registro traz a baila conexões entre nome como expressão de si, da honra e do lugar social.

"Se eu pudesse pagar aquilo ali eu pagaria, porque pra mim... é questão de honra." (C6)

"Me sinto até um marginal, que na verdade eu não sou, né? Sou trabalhador, trabalho... e aí eu me sinto assim como se eu fosse excluído da sociedade em relação a essa situação, né." (C13)

“Tem que procurar um meio, né(...)porque(...) impossível que vai mandar prender todo mundo? Não tem cadeia pra todo esse povo que tá devendo por aí! Não, porque falaram pra mim que cartão dá cadeia, né..." (C11)

Esse consumidor, um senhor idoso e bastante humilde, chega a cogitar que a inadimplência constitua um "crime" passível de reclusão, o que evidentemente é uma ideia fantasiosa. Contudo, será que ela não estaria a sinalizar o quão reprovável moralmente afigurase tal condição?

O registro em cadastros de inadimplentes gera restrições objetivas, como algumas enfrentadas pelos entrevistados: não poder comprar a crédito (precisar recorrer a terceiros quando isso é necessário), não poder abrir conta em banco, não poder vender imóvel próprio via financiamento, não conseguir alugar imóvel. Limitações que dizem respeito basicamente ao âmbito financeiro-comercial, o que se mostra pertinente. Contudo, o "nome sujo" no SPC "suja" outros campos. A prática de certas instituições, que fazem consulta nesses cadastros em determinadas circunstâncias, só reforça a ligação entre 
estar inadimplente e ser alguém não confiável, não digno de alguns benefícios ou mesmo de uma oportunidade de emprego.

"Mesmo com bolsa, algumas escolas, tipo o XX, mesmo conseguindo bolsa, eles olharam o nome pra ver se eu cons(...) se eu tava com o nome sujo ou não(...) pra poder ceder a bolsa." (C20)

"Na seleção, a recrutadora falou: "quem estiver no SPC não precisa nem preencher a ficha'... Aí um monte de gente foi embora!" (C1)

"Tu tá devendo, né? E não vão te dar emprego; como é que eu vou pagar então aquela minha dívida? Né? Então, eu tenho que ter um emprego pra pagar! Não é porque eu tô devendo que eu sou uma pessoa má!" (CC21)

No primeiro caso, o nome "limpo" constituía pré-requisito para obtenção de bolsa naquela escola. Qual seria o motivo, já que o pleito era para bolsa integral, que não envolveria pagamentos? Nos outros, aparece algo muito comum: trabalhadores inadimplentes tem dificuldade para se recolocar no mercado de trabalho, pois várias empresas não querem tê-los em seus quadros. A última fala, ao trazer (buscando negar) a associação entre inadimplência e maldade, parece explicitar a desconfiança e o estigma moral a que estão sujeitos aqueles que se encontram em tal condição.

É interessante observar como a concepção individualizante do superendividamento se sobrepõe à própria experiência pessoal. Entre os entrevistados, a consumidora 2 foi a que acabou (super)endividada em função do maior número de acidentes de vida. Contudo, falando do seu receio em tentar mudar de emprego quando estava com o nome no SPC, ela disse: "Pô, como é que uma empresa vai contratar um funcionário que não sabe administrar sua própria vida, entende? Eu não contrataria. Se fosse contratar, eu questionaria, entende?" Aqui se plasma a ideia de que superendividamento/inadimplência é fruto de falhas do indivíduo, de algo que ele poderia administrar/contornar, mas não fez. Em decorrência dessa visão, ou ele é diretamente descartado ou fica "sob suspeita". Se a própria entrevistada, que passou pela situação, tem o ímpeto primeiro de rejeitar, o que se pode esperar das empresas - e das pessoas em geral?

A existência dessa espécie de "manto de suspeição", que espreita quem deve e não consegue reunir recursos para pagar, talvez possa elucidar, pelo menos parcialmente, o fato de que diversos entrevistados ou não comentavam sua situação com outras pessoas ou faziam isso sob condições específicas - quando a intimidade ou a identificação poderia suspender o risco imaginário de um mau julgamento? Compartilhar dentro do núcleo familiar apareceu na fala de muitos, seja por escolha/necessidade de dividir a situação ou porque inevitável haja vista a publicização das cobranças. Por outro lado, algumas falas apontaram o caráter "individual" do problema: ele seria concernente a cada um - ou a cada família. 
“Minha mãe sabia, sempre soube! Desde o início... até porque as cartinhas [com cobranças] sempre iam pra a casa da minha mãe." (C21)

"A gente é bem amiga, a gente comenta como a gente faz, assim... mas só com ela! Só com esse casal, que é muito amigo nosso..." (C12)

“Já, já comentei [com o pessoal do trabalho], até porque lá no meu serviço tem bastante gente que tem a mesma situação." (C13)

"É que cada um tem a sua vida... isso aí é uma teoria e uma prática que é confirmada. Cada um tem a sua vida, né? $\mathrm{E}$ a gente não quer envolver ninguém. O máximo que eu poderia envolver é a minha mãe." (C24)

Alguns aspectos foram bastante reportados pelos participantes da pesquisa: a menção de que sua situação de (super)endividamento não decorreu de "extravagâncias"; a referência às restrições e/ou privações cotidianas que tal condição impõe; a ênfase de que o consumo atual restringia-se ao básico; e, por fim, a recorrente alusão às atividades de lazer, para descartá-las como inviáveis.

"Eu tô passando dificuldade, mas o que me consola é que as minhas dívidas não são assim dívidas de coisas supérfluas, entendeu?" (C4) "Esse mês não sobrou nem pro remédio dele, que ele usa..." (CC11)

"Mas nós estamos abrindo mão de praticamente tudo! A gente não sai de casa pra ir numa pracinha, tomar um sorvete! Porque(...) vai fazer falta depois.... Pô, tu te priva, aí tu deixa de consumir o básico..." (C8)

"Lazer nem pensar, né?! Porque dinheiro para isso não... O lazer da gente é só a televisão, né... Só esse." (C14)

Talvez tenha sido a negação da possibilidade de desfrutar momentos de lazer, presente na fala de muitos participantes, que tenha chamado nossa atenção e sido o elemento que fez com que relacionássemos os aspectos arrolados acima. Já havíamos pontuado que os entrevistados buscavam se despregar do estereótipo de desonestos, de consumidores inconsequentes (ou correlatos), e, evidentemente, quem está imerso em dívidas traz a baila uma série de dificuldades que enfrenta. Contudo, nos pareceu que, em vários casos, falar sobre as restrições, sobre uma vida sem "folga", denotava algo da ordem de uma penitência a ser cumprida, de um "castigo" a que eles tinham que se resignar. Neste sentido, conjecturamos que talvez se tratasse de uma espécie de mecanismo ou manobra (simbólica) que visaria expiar a culpa - suposta ou imputada socialmente, assumida a despeito das circunstâncias adversas enfrentadas - por terem "caído" em tal situação. Questões importantes, que retomamos no curso da próxima seção.

\section{Sobre o controle das condutas: o limiar do (des) crédito}


Ao abordar o dissolver das sociedades disciplinares no "magma" das sociedades de controle, Deleuze (2008), no texto Post-scriptum sobre as sociedades de controle, afirma que, nessa configuração social, "o homem não é mais o homem confinado [em instituições], mas o homem endividado" (p.224), ressalvando que o capitalismo seguia mantendo um contingente de miseráveis "pobres demais para a dívida" (Idem). Como essa asserção carece de maiores articulações, cabe indagar: de que dívida fala o filósofo? Congruente com tal regime social que, há algum tempo, passou a despontar, onde "os controles são uma modulação (...) [e no qual] nunca se termina nada" (Idem, p. 221), pensamos que se trata de uma dívida sujeita à modulagem constante, que não finda, que desliza entre acepções.

(...) o sistema dívida/crédito não é apenas motor econômico, mas também uma técnica para governar as condutas dos indivíduos. O sistema da dívida [financeira e moral, cuja origem, segundo Nietzsche, é a mesma] faz circular, por sua vez, a culpa e a "responsabilidade" entre os governados. (LAZZARATO, 2009, p. 88)

Sem dúvida, bolsões de miséria são encontrados mundo afora, mas, cada vez mais, o crédito (e a dívida) está ao alcance de uma parcela crescente da população - e, dependendo das circunstâncias, também o descrédito, com toda uma carga de sofrimento psíquico, como mostramos na seção anterior. Por isso, é vital lançar um olhar analítico mais aprofundado sobre os diferentes aspectos que se agenciam na produção de indivíduos endividados e superendividados e do que se afigura como um correlato, o limiar entre (ter) crédito e (estar em) descrédito.

Trabalhamos com uma perspectiva teórica que entende a subjetividade como uma construção que se processa socialmente. Assim, pontuamos que o modo-indivíduo - que atravessou os ditos sobre superendividamento -, apesar de estar sendo a forma hegemônica de constituição subjetiva (sustentada em múltiplos campos discursivos e por variadas práticas sociais), é apenas um dos modos de subjetivação possíveis, seu engendramento respondendo a diversas linhas de força que se cruzaram na Modernidade. São muitos os aspectos que poderíamos trazer à baila para discorrer acerca da produção do indivíduo moderno, mas focamos dois: as noções de razão, autonomia e interioridade que se conjugam nessa concepção; e aquilo que Foucault (1995) chamou de práticas divisórias.

Em relação ao primeiro aspecto, Siqueira (1999, p. 74) atribui a Descartes a primeira formulação da "concepção de indivíduo soberano, centrado em si mesmo, unificado, dotado de razão, consciência e poder de ação, essencialmente o mesmo ao longo de 
sua trajetória no mundo". Concepção que foi sendo matizada; como pontua Mancebo (2004), existem várias formas de individualização, atravessadas por movimentos como o liberalismo, o racionalismo administrativo, tecnocrático e disciplinar, o individualismo e coletivismo românticos. Mas, o que importa trazer aqui é que a naturalização de tal concepção, que implica a cisão entre indivíduo e sociedade, é chave para entender a imputação de responsabilidade ao consumidor-indivíduo quanto ao superendividamento - mesmo quando ele decorre de acontecimentos que passam ao largo de sua vontade/ação (acidentes de vida) e/ou de dados que escapam a sua razão (lógica do crédito). Por outro lado, cabe assinalar que, constituída a experiência da subjetividade privatizada (Figueiredo, 1996), abre-se espaço para a emergência de uma ciência psicológica. Essa, no que hoje se designa como abordagem tradicional, a partir dos saberes e práticas que produziu, só fez enrobustecer a noção de sujeito dotado de uma interioridade, localizando nessa a origem das características psíquicas e das diversas psicopatologias.

Neste ponto, podemos fazer uma articulação com as práticas divisórias implementadas no regime disciplinar. Para tanto, é importante pontuar que a disciplina é produtora de individualidade: o indivíduo é efeito de uma rede de poderes e saberes. E, diferente de se alicerçar na lei, o poder moderno ser exerce no domínio da norma, que regula tanto a vida dos indivíduos quanto das populações. Lançando mão de uma série de táticas (vigilância, exame, etc.), o poder disciplinar adestra e controla os indivíduos, definido os aptos e os inaptos, demarcando o normal e o patológico (Foucault, 2008). Assim, "o sujeito é dividido no seu interior e em relação aos outros. Este processo o objetiva. Exemplos: o louco e o são, o doente e 0 sadio, os criminosos e os 'bons meninos'” (Foucault, 1995, p. 231).

Neste contexto, determinada Psicologia acabou tornando-se crucial na produção do modo-indivíduo ao adotar a noção de interioridade psicológica como substância fundante do sujeito. E, atualmente, tem produzido e difundido explicações individualizantes no que tange ao âmbito do consumo; essas, que tem significativo peso nas maneiras como nos identificamos e avaliamos, passam, via de regra, pela ideia de falta de controle: impulsividade, compulsão, falta de consciência ou descontrole econômico.

Ter dívidas e não conseguir pagá-las, inadimplir, traz como espectro ou consequência ter o nome registrado em órgãos como SPC ou SERASA. A despeito de não serem instituições de confinamento/sequestro (como a prisão ou o hospital psiquiátrico), estar vinculado às mesmas também institui uma linha divisória discriminatória, (ainda) produz uma marca moral, acarreta um estigma, gera sofrimento: de um lado, o bom pagador; de outro, 0 caloteiro, o mau-caráter, o que fica/é marginalizado. 
Cabe agora discorrer sobre porque colocamos a expressão ainda entre parênteses, enfatizando-a. Pensamos especialmente nas duas consumidoras para quem o (super)endividamento não se mostrava problemático, que disseram se virar com determinada modalidade de crédito, tapar uma dívida, abrindo outra. A partir de tais posições, cabe uma provocação: seria essa indiferença ante 0 superendividamento/inadimplência o horizonte do sistema crédito/dívida? E quais seriam seus desdobramentos sociais e econômicos?

Sim, porque a posição de endividado é cada vez mais fomentada na sociedade e economia contemporânea, a ponto de constituir uma condição que baliza várias outras; existe todo um incitamento para aumentar o consumo via antecipação de recursos, viabilizá-lo através das mais plurais modalidades de crédito.

Hoje, as pessoas não são mais enquadradas pela miséria, mas pelo consumo. Tal como no século XIX, mesmo se é sob um outro modelo, elas continuam capturadas em um sistema de crédito que as obriga (se compraram uma casa, móveis...) a trabalhar todo santo dia, a fazer hora extra, a permanecer ligadas. (Foucault, 2010, p. 67)

Mais do que uma instituição econômica, para Baudrillard (2006), o crédito constituiu uma dimensão fundamental de nossa sociedade, traça uma ética nova. O autor afirma que, durante um bom tempo, certo pudor pressentiu no crédito um perigo moral, colocando a compra à vista no rol das virtudes burguesas. Mas, se resistências psicológicas foram amainando

(...) é porque talvez no fundo todos os nossos objetos sejam hoje vividos como objetos a crédito, como fianças da sociedade no todo, fianças sempre revisáveis, sempre flutuantes, tomadas por uma inflação e desvalorização crônica. (Idem, pp. 167-8)

Neste sentido, por e para integrar a sociedade de consumidores, de tal sorte a não se tornar um consumidor falho, um inválido marcado para a exclusão (Bauman, 2008), entramos no patamar da dívida constante, sempre renovável. O que se mostra um excelente negócio, tanto que Bauman (2010) afirma que, para bancos e empresas de cartão de crédito, o “'o devedor ideal' é aquele que jamais paga integralmente suas dívidas" (p.30), pois é justamente o serviço da dívida que gera os maiores lucros.

Assim, para o sistema é desejável que os indivíduos estejam endividados - mas não superendividados/inadimplentes. Há, portanto, que gerir tal situação, que se refere ao conjunto dos indivíduos, diz respeito aos movimentos da população. Neste sentido, 
como já referimos, uma série de agências vem monitorando os patamares de endividamento/inadimplência da população, de forma a lançar mão de táticas (como modulação de taxas de juros, elevação/diminuição de impostos sobre produtos específicos) para bem governar a população, para regular suas condutas (Foucault, 2008).

Cabe assinalar que a disciplina tinha como referentes padrões mais fixos, já o âmbito dos chamados dispositivos de controle é pautado por percentagens, é afeito às modulações. Por isso, talvez em função da dificuldade de lidar com essa nova ordem muito mais móvel (marca do sistema financeiro atual) que tantos consumidores se surpreenderam com a "trajetória" de suas dívidas. Definitivamente, não há qualquer equiparação possível entre a lógica das (antigas) prestações (fixas) e a compra (mesmo parcelada) em um cartão de crédito - que oportuniza o pagamento mínimo e a "rolagem" de boa parte do saldo devedor no sistema rotativo. Não entendendo a atual lógica do crédito, a inadimplência (para quem não volta ao sistema a fim de contratar empréstimos para "pagar" empréstimos), é quase inevitável - e traz consigo um padecimento moral.

Lazzarato (2009) diz que o capitalismo contemporâneo incentiva o endividamento, e que também responsabiliza os indivíduos pelo que chama de déficits molares (seguridade social, seguro saúde, etc), eliminando a carga culpabilizadora do endividamento molecular. Contudo, com base no que os participantes da presente pesquisa externaram, o peso moral pelo endividamento individual se faz ainda muito presente. Talvez pelo fato da "democratização" do crédito ser recente no Brasil, o que se tem é uma (parte da) população sem a plena familiarização e inserção na cultura do crédito/endividamento assim, a torção apontada pelo autor ainda estaria se processando. Pode ser questão de tempo para que se crie um acordo social que abone aqueles que sabem se manter "otimamente endividados individualmente" e que Ihes inculque (mais as) obrigações com os chamados déficits estruturais. O que constatamos foi basicamente uma forma de incidência do peso da dívida; estar (super)endividado é: estar culpado, impotente, insone, privado de muitas coisas, sem possibilidade de fluir momentos de lazer; ter que arcar com desconfianças e reprovações - e tudo isso parece soar, se não "justo", pertinente a quem se vê devedor.

Importante retomar, com Fimyar (2008, como citado em Veiga-Neto \& Traversini, 2009), que o que está em questão na governamentalidade é a criação - através de técnicas de controle, normalização e moldagem das condutas - de sujeitos governáveis, sendo que, neste processo, entram em relação "o governamento do Estado (política) e o governamento do eu (moralidade)" (p.16). Assim, a individualização do superendividamento e o estigma moral que recai sobre quem se encontra nessa situação não são acessórios. 
Ao contrário, a culpa, a vergonha, a (autopenitência da) privação do lazer, a eventual "compreensão" das cobranças e reprovações, entre outros aspectos, são basilares para a produção de sujeitos em dívida - financeira e moral.

No livro Genealogia da Moral, Nietzsche (1998) aborda esse sentir ao tratar da construção social da má-consciência. Para ele, é longa a história da origem da responsabilidade, cujo fruto maduro é o indivíduo soberano, que se orgulha de sua consciência. Dissertando sobre o conceito moral de culpa, diz que esse procede do conceito material de dívida. Expõe que, na antiga relação entre credor e devedor, esse emprenhava algo que possuía - no limite, seu corpo; no caso de falta de pagamento, "o credor podia infligir ao corpo do devedor toda sorte de humilhações e torturas" (Idem, p.54); a lógica dessa compensação era substituir o ganho relacionado ao dano, "por uma espécie de satisfação íntima, concedia ao credor como reparação e recompensa" (Idem). Andrade (2010), que analisa essa obra, identifica e sistematiza quatro figuras da dívida: entre comunidades, entre comunidade e indivíduo, entre comunidade e ancestrais, e a dívida moral.

A partir da releitura das proposições desses autores, conjeturamos sobre como elas poderiam inspirar uma compreensão das atuais relações entre credores e devedores, e do que tem marcado as situações de superendividamento. Conforme Andrade (2010), antes da identidade pessoal estar centrada no indivíduo, ela era determinada pela pertença ao grupo. Em função disso, pensa que o primeiro nível do sujeito de direito remetia às comunidades de estirpe, que as trocas e dívidas se davam entre comunidades; "foi entre elas que pôde haver valorações em relação a vantagens e desvantagens numa troca ... [e, com isso] uma comunidade pôde atestar sua posição em relação a outras em termos de poder" (Idem, p. 286). Apesar da centralidade do indivíduo hoje, poder-se-ia, no que tange às relações de consumo, pensar em embates entre "comunidades" de fornecedores e de consumidores. Os primeiros, como "sujeito de direito", para ter mais poder na negociação e/ou para punir a outra comunidade quando da dívida, lançam mão de dispositivos como os cadastros de inadimplentes. Já os consumidores, "comunidade" dispersa, só alcançam certo "poder de barganha" quando respaldados por dispositivos legais e jurídicos (como o Código de Defesa do Consumidor - CDC, o Projeto focalizado neste artigo) que visam (re)estabelecer algum patamar de equilíbrio, de justiça.

Agora, tomando todos como integrantes de uma mesma comunidade, passamos à figura da dívida entre essa e o indivíduo. Para Nietzsche (1998) "a comunidade mantém com seus membros essa importante relação básica, a do credor com seus devedores. Vive-se numa comunidade, desfruta-se as vantagens de uma comunidade" (p.60). Quando um indivíduo, que se comprometeu com a comunidade, 
quebra a palavra e o contrato com a mesma, "ele não apenas será privado de todos esses benefícios e vantagens, como é justo doravante Ihe será lembrado o quanto valem esses benefícios" (I dem, p. 61). Assim, ao fazer parte de uma sociedade de consumo, que tem no crédito um pilar basal, o consumidor pode usufruir o benefício que chamamos de antecipação de recursos, comprometendo-se com suas regras (explícitas e implícitas). Ao inadimplir, ele estaria "traindo" o sistema; logo, como uma forma de compensação pela sua dívida, além de arcar com as restrições objetivas que tal condição acarreta, o consumidor terá que se haver com o castigo moral que lhe cobrirá, que o lembrará cotidianamente que passou a ser um "fora-da-lei" (Idem). Por isso, ele é incitado, cada vez mais, a se "monitorar", a não atravessar (mesmo que seja ao custo de mais endividamento) o limite que opõe quem tem crédito daqueles que estão em descrédito.

Para refletir sobre a terceira figura da dívida, entre comunidade e seus ancestrais - aqueles que lhe teriam legado sua força e que "podem ser valorizados até se elevarem ao estatuto de deuses" (Andrade, 2010, p. 289), é preciso uma torção um pouco maior. Não será à (antiga) sociedade de produtores que se fará semelhante reverência. Pensamos que, se hoje existe um culto, talvez seja realmente a uma entidade "etérea e divinizada", o Capital. A esse "deus" devemos a configuração social que conhecemos; então, diante de seu "altar", oferecemos nossa vida "em sacrifício": nos tornamos (sempre, mais e mais) consumidores e endividados.

Por fim, a dívida moral, que remete à interiorização do sentimento de dever, está na origem da má-consciência, pela qual "o devedor passa, não só a se sentir culpado, como também a ter consciência de dever sofrer" (ibidem). Conhecendo a ética que vigora na sociedade, o sujeito aceita suas implicações positivas e negativas; portanto, o devedor concorda que precisa pagar por sua dívida; caso não possa saldá-la "na mesma moeda", um quantum de sofrimento lhe será requerido como uma restituição simbólica ao credor. Desse modo, processa-se um deslocamento na significação do ressarcimento à sociedade: uma disposição ao sofrimento, por parte do devedor, o faria redimir-se e aliviar-se da culpa, ainda que pouco a pouco, num processo quase inesgotável, a prestações (de prestar, servir, conceder, dar, dedicar). É assim que a questão do débito deixa de possuir somente um caráter jurídico e ganha um estatuto moral. E aqueles que se encontram em situação de superendividamento acabam enredados na teia do estigma moral, tem uma vida marcada pelo mal-estar, restrições e privações, sem "folga".

\section{Considerações finais}


Para encaminhar a finalização deste artigo, cabem novas provocações: seria a ética do crédito (Baudrillard, 2006) a forma de assegurar o (sempre visado, prometido) desenvolvimento social? No contexto dessa ética, em que consistiria tal desenvolvimento? A quem abrangeria? Desejamos, de fato, bancar (todos) os desdobramentos dessa ética, da expansão crescente do sistema dívida/crédito (Lazzarato, 2009)? Acompanhamos Foucault (1995) que diz que o objetivo político hoje, para além de descobrir quem somos, está em "promover novas formas de subjetividade através da recusa deste tipo de individualidade que nos foi imposto há vários séculos" ( $p$. 239).

De acordo com Bauman (2010, p.35), “ainda não começamos a pensar seriamente sobre a sustentabilidade dessa nossa sociedade alimentada pelo consumo e pelo crédito". Para tanto, acreditamos ser fundamental elucidar os mecanismos, até então invisibilizados em sua (re)produção ao longo do tempo, que engendram os modos de subjetivação vigentes - e trabalhar para que formas alternativas de ser possam tomar corpo, expandir-se.

Evidentemente que tais mecanismos não estão circunscritos ao âmbito do Estado, mas pensamos que é importante também responsabilizá-lo pelo que se produz, não só em termos econômicos, mas também no nível ético e subjetivo. Assim, defendemos que a maquinaria estatal precisa transcender a esfera do controle e monitoramento de fenômenos sociais como o superendividamento, deve buscar entendê-los em sua complexidade, ponderar sobre seus desdobramentos, e intervir ativamente para o enfrentamento das situações que hoje eclodem.

Neste sentido, se fazem necessárias políticas públicas que estejam em consonância com as vicissitudes evidenciadas no bojo das situações de superendividamento - que incluem acidentes de vida e o que chamamos aqui de lógica do crédito. Tais iniciativas devem colaborar para o empoderamento dos sujeitos, o que, ao invés de residir no puro acesso ao crédito, viabiliza-se muito mais no acesso à informação sobre o mesmo - primordialmente, na possibilidade de compreensão dos seus meandros e das suas (múltiplas) implicações.

Ações que já estão sendo desenvolvidas, como o Projeto do judiciário gaúcho referido neste escrito, são louváveis uma vez que coletivizam a situação de superendividamento: ao convidar todos os credores a sentarem-se juntos ao seu cliente, um outro olhar, postura e negociação podem advir. Contudo, por mais que isso se configure como um diferencial para cada consumidor, há que se empreender, no seu âmbito, uma nova coletivização. A sistematização dos "casos" e a visibilização dos fatores que Ihes atravessam são fundamentais para que, além de se encaminhar soluções pontuais, se possa aprender com eles, cartografar as intrincadas linhas que constituem o 
fenômeno do superendividamento, de modo a atacá-las global e politicamente.

Outra iniciativa que pode ser promissora é o Decreto no 7397 (2010) que criou a Estratégia Nacional de Educação Financeira, que pretende possibilitar ao cidadão, como medida "preventiva", um entendimento mais pleno e prático das relações financeiras para que passe a gerilas de modo adequado. Queremos crer que, assim, o Estado caminha em direção a uma compreensão do fenômeno em seu caráter social, de causas provindas não dos sujeitos, mas de toda uma ética voltada ao consumo e ao hedonismo propiciado (e preconizado!) pelo oferecimento do "crédito fácil". Se efetivamente sair da "cantilena" que prega que tudo se equacionará se o consumidor for "consciente", não deixa de ser uma frente válida. Pois, como desejamos ter mostrado no presente estudo, um nível muito mais basal necessita ser trabalhado, a saber, a problematização desta constante impulsão ao consumo via crédito, que tem impregnado nossa cultura, para que aí se possa fazer frente a ela e desenvolver outras maneiras de se viver. Nesse sentido, cabe sempre o questionamento: a quem isso interessa?

\section{Referências}

Andrade, V. A. G. F. (2010). Dos tipos fundamentais de dívida (schuld) para uma genealogia da moral. Cadernos da Graduação (Campinas), 8, pp. 285-292.

Barros, R. B. (2007). Grupo: a afirmação de um simulacro. Porto Alegre: Sulina/Editora da UFRGS.

Baudrillard, J. (1995). A sociedade de consumo. Lisboa: Edições 70.

Baudrillard, J.(2006). O sistema dos objetos. São Paulo: Perspectiva.

Bauman, Z. (2008). Vida para consumo. Rio de Janeiro: J orge Zahar.

Bauman, Z. (2010). Vida a crédito. Rio de Janeiro: Jorge Zahar.

Confederação Nacional do Comercio de Bens, Serviços e Turismo (2011). Pesquisa Nacional CNC - Endividamento e Inadimplência do Consumidor, dezembro de 2011. Recuperado em 07 dezembro, 2012, de

<http://www.cnc.org.br/sites/default/files/arquivos/peic_dezembro_1 1.pdf $>$.

D'Andrade, W. (2012). Inadimplência cresceu 22,3\% em 2011, indica pesquisa. Recuperado em 25 fevereiro, 2014, de <http://veja.abril.com.br/noticia/economia/inadimplencia-cresceu22-3-em-2011-indica-pesquisa $>$.

Decreto n.7.397, de 22 de dezembro de 2010 (2010). Diário Oficial [da] República Federativa do Brasil, Poder Executivo, Brasília, DF, 23 dez 2010, p. 7. Recuperado em 12 janeiro, 2012, de 
<http://www.planalto.gov.br/ccivil_03/_Ato2007-

2010/2010/Decreto/D7397.htm>

Deleuze, G. (2008). Conversações. São Paulo: Ed. 34.

Figueiredo, L. C. (1996). Psicologia: uma introdução. São Paulo: EDUC.

Foucault, M. (1995). O sujeito e o poder. In H. DREYFUS, \& P. Rabinow (Org.). Michel Foucault, uma trajetória filosófica: para além do estruturalismo e da hermenêutica.(pp.231-249). Rio de Janeiro: Forense Universitária.

Foucault, M. (2000). A arqueologia do saber. Rio de Janeiro: Forense Universitária.

Foucault, M. (2008). Estratégia, poder-saber. Rio de Janeiro: Forense Universitária.

Foucault, M. (2010). Segurança, território, população. Rio de janeiro: Forense Universitária.

Frade, C., \& Magalhães, S. (2006). Sobreendividamento, a outra face do crédito. In C. L. Marques, \& A. L. Cavallazzi (Org.). Direitos do consumidor endividado. (pp.23-43). São Paulo: Revista dos Tribunais. Guttmann, R., \& Plihon, D. (2008). O endividamento do consumidor no cerne do capitalismo conduzido pelas finanças. Economia e Sociedade (Campinas), 17, 575-610.

Lazzarato, M. (2009). Sobre a crise: finanças e direitos sociais (ou de propriedade). Lugar Comum, 27, pp. 83-90.

Lima, C. C., \& Bertoncello, K. (2010). Superendividamento aplicado: aspectos doutrinários e experiência no Poder Judiciário. Rio de Janeiro: GZ Ed.

Mancebo, D. (2004). Individuo e psicologia: gênese e desenvolvimentos atuais. In D. Mancebo, \& A. M. Jacó-vilela Psicologia social: abordagens sócio-históricas e desafios contemporâneos (pp. 35-48). Rio de Janeiro: UERJ .

Marques, C. L., \& Cavallazzi, A. L. (2006) Direitos do consumidor endividado. São Paulo: Revista dos Tribunais.

Marques, C. L. (2006). Sugestões para uma lei sobre o tratamento do superendividamento de pessoas físicas em contratos de crédito ao consumo: proposições com base em pesquisa empírica de 100 casos no Rio Grande do Sul. In C. L. Marques, \& A. L. Cavallazzi (Org.). Direitos do consumidor endividado (pp. 255-309). São Paulo: Revista dos Tribunais.

Nietzsche, F. W. (1998). Genealogia da moral: uma polêmica. São Paulo: Companhia das Letras.

Orlandi, E. (2000). Análise de discurso. Campinas: Pontes.

Siqueira, M. J. T. (1999). Refletindo sobre a noção de sujeito: alguns apontamentos. Educação, subjetividade e Poder, 6, 73-81.

Veiga-Neto, A., \& Traversini, C. (2009). Por que governamentalidade e educação? Educação \& Realidade, 34(2), 13-19. 


\section{Endereço para correspondência \\ I nês Hennigen}

Instituto de Psicologia da Universidade Federal do Rio Grande do Sul, Porto Alegre, Rio Grande do Sul, Brasil

Endereço: Rua Ramiro Barcelos, 2600, Floresta, CEP 90035-003, Porto Alegre - RS, Brasil

Endereço eletrônico: ineshennigen@gmail.com

J oão Paulo Borges

Universidade Federal do Rio Grande do Sul, Porto Alegre, Rio Grande do Sul, Brasil

Endereço: Rua Ramiro Barcelos, 2600, Floresta, CEP 90035-003, Porto Alegre - RS, Brasil

Endereço eletrônico: joaopauloborges@gmail.com

Recebido em: 13/02/2012

Reformulado em: 20/12/2013

Aceito para publicação em: 20/12/2013

Acompanhamento do processo editorial: Alexandra Cleopatre Tsallis

\section{Notas}

* Doutora em Psicologia pela PUCRS, docente do PPG em Psicologia Social e Institucional do Instituto de Psicologia da Universidade Federal do Rio Grande do Sul, Porto Alegre, Rio Grande do Sul, Brasil

** Psicólogo pela Universidade Federal do Rio Grande do Sul, Porto Alegre, Rio Grande do Sul, Brasil.

$$
\begin{aligned}
& 1 \text { Disponível em <http://www.cnc.org.br/central-do- } \\
& \text { conhecimento/todas?categoria\%5B\%5D=67> , acessada em 07/12/2012. } \\
& 2 \\
& \text { Disponível }
\end{aligned}
$$

<http://www.araraquara.com/noticias/economia/2012/01/11/inadimplencia-

cresceu-223-em-2011-indica-pesquisa.html>, acessado em 12/01/2012.

3 Em dois casos, as companheiras dos participantes estiveram presentes na entrevista; quando trazemos suas posições, usamos duas letras $C$ para marcar que trata-se da companheira do consumidor em questão.

4 Uma questão que dirigimos aos entrevistados foi se eles consideravam a expressão superendividado apropriada para caracterizar sua condição naquele momento de vida. A maior parte respondeu que sim, mas não teceu maiores comentários a respeito (os que fizeram, centraram-se no montante da(s) dívida(s) para concordar com o prefixo super). Ter dívidas e não dispor de recursos para quitá-las é que se afigurava como problemático, o que os mobilizava. Refletindo sobre isso, conjeturamos que, uma vez que todos que ali estavam tinham aderido ao Projeto de Tratamento das Situações de Superendividamento, negar e/ou contestar tal expressão poderia representar (imaginariamente) sua não qualificação para usufruir do mesmo. De qualquer modo, a questão não desencadeou - como cogitávamos - reflexões sobre tal "categoria identificatória" e/ou sobre os critérios para alguém ser assim designado. Deste modo, mesmo que haja uma caracterização consagrada no campo do Direito, ela parece escapar à população. Por isso, optamos por colocar o prefixo entre parênteses, uma forma de traduzir a (aparente) falta de borda entre a condição de quem está endividado e superendividado.

${ }^{5}$ Omitimos todas as referências a instituições, substituindo seu nomes por letras aleatórias. 